\title{
Employee Behavior in Organizations. On the Current State of Research ${ }^{* *}$
}

The article gives an overview about scientific research on individual behavior in organizations. A number of reasons are discussed why it is difficult to obtain a coherent body of knowledge about this topic, some of them meta-theoretical and methodological, others political, organizational and ideological, e.g. the existence of different schools of psychology, one-sided and interest-laden views, the dominance of survey methodology, measurement problems, the submission of researchers to dominant styles of publishing. The article further reports on main insights about the effects of stable and variable personal traits, and of situational conditions on employee behavior and about practical consequences. The conclusion is that there is a lot of well-founded knowledge, especially about the aptitudes of employees, but on the other hand one finds remarkable ignorance on behaviour which has no direct relation to performance and on the impacts of specific work and organizational conditions.

Key words: organizational behavior, organizational psychology, performance, leadership, personal traits (JEL: J23, J24, J28, M12, M54)

* Prof. em. Dr. Dr. h.c. Lutz von Rosenstiel, Lehrstuhl für Organisations- und Wirtschaftspsychologie, Ludwig-Maximilians-Universität, Leopoldstr. 13, 80802 München, Germany. E-mail: boegel@psy.uni-muenchen.de.

** Article received: November 11, 2010

Revised version accepted: December 3, 2010. 
People's behavior is analyzed by a number of sciences. Countless monographies, anthologies, essays and journal articles focus on it, whereby the perspectives of the individual disciplines sometimes differ significantly. The view of psychology is, of course, of particular importance - a subject which defines people's experience and behavior as its object. The available evidence from this field holds in principle certainly also true for employee behavior in organizations. As any behavior is always a function of person and situation, general findings are one-sided and lacking context. They do not consider the specific conditions which this article deals with: those of an organization.

With such a limiting perspective, human behavior is also and specifically considered as a function of those conditions which exist within organizations. It is mainly work and organizational psychology, industrial sociology and the behavioral approach in business studies that deal with it, but also a number of other subjects such as labor and commercial institutional law, industrial science, ergonomics, occupational medicine, etc. When looking at the research findings of these disciplines - of organizational psychology in particular - it becomes obvious that there is considerable one-sidedness with regard to both content and methodology, while some sub-topics are researched intensively and others nearly completely neglected.

Personal determinants of work and performance behavior were analyzed in particular detail, whereby the relatively stable characteristics of the person form the basis for personnel assessment and selection in practice, while the variable and alterable characteristics frequently become the subject of personnel development. The varying general conditions of the particular job and the surrounding organization were also analyzed, whereby results were - among other things - incorporated into concepts of industrial engineering, and team or organizational development with the aim of behavioral control.

\section{Human behavior: subject of many sciences}

Considering that scientific thinking is traditionally characterized by aspect specialization (v. Rosenstiel, 1977), which is also reflected in the structure of faculties at universities, it is not surprising that a research subject as complex and multifaceted as human behavior is viewed from very different perspectives and prevailing cultures in various knowledge disciplines. Theology, ethics, jurisprudence, and pedagogy have a rather normative orientation, various cultural studies have a rather interpreting view, but also history, specific fields coming from the scientific perspective such as medicine but also ethology or behavioral biology as well as sociology, political science, communication science and particularly psychology with their accentuated empiric-positivistic view, which - as previously mentioned - often makes human experience and behavior its subject. The interdisciplinary cooperation of all these research areas, which would technically be necessary, often fails because of incompatibilities in the terminology, methods, the ideological prejudice and the culture in the individual disciplines. Therefore there are only few basic theoretical assumptions which are shared across the disciplines and research results which are generally accepted as the current state of knowledge. 


\section{The perspective of psychology}

This article will cover the findings of psychology - certainly in a restricted way - , which certainly does not mean that it was psychologists with degrees and Ph.D.s who worked them out but scientists who have dealt with human experience and behavior explicitly on an empirical basis. There was a brief attempt in US American psychology at the beginning of the last century to eliminate experience as a subject of empirical psychology, as it was claimed that it cannot be verified objectively, i.e. cannot be registered by independent observers. This led to a more differentiated methodology but ultimately had no sustainable impact regarding contents. Research methodology would traditionally rely on surveys to record experience, recently also increasingly on psychophysical indicators, in particular those originating from brain research, while behavior was analyzed by observation procedures of varying methodology - ranging from unsystematic procedures to complex experimental designs.

\subsection{Schools of thought}

Although they deal with the same subject, different schools of psychology (Lewin, 1936; Bischof, 1981) have very different basic approaches. A distinction - in a rather rough classification - can be made between four different schools of psychology. Scientific psychology, which has physics as its model, focuses strongly on the experiment and seeks to put the results into a mathematical form; humanistic psychology, which emphasizes the incomparability and individuality of humans, is oriented towards history as a model and prefers understanding as a methodology; social-scientific psychology whose model is sociology, which usually assumes that human experience and behavior are continuously learned and imprinted by social factors, and finally a biological psychology, which interprets human experience and behavior primarily as a result of the biological evolution process, therefore emphasizing strongly its genetic foundation. This can be seen in Figure 1.

Figure 1: Schools of psychology

\begin{tabular}{l|l|l|l|l|l}
\hline & Model & \multicolumn{1}{|c|}{ Characteristics } & \multicolumn{1}{|c|}{$\begin{array}{l}\text { Intellectual } \\
\text { fathers }\end{array}$} & $\begin{array}{l}\text { Pioneers in } \\
\text { psychology }\end{array}$ & $\begin{array}{c}\text { Current scientific } \\
\text { representatives }\end{array}$ \\
\hline $\begin{array}{l}\text { Scientific } \\
\text { psychology }\end{array}$ & Physics & $\begin{array}{l}\text { Lab experiments, formulation of } \\
\text { general laws of experience and } \\
\text { behavior in mathematical form }\end{array}$ & G. Galilei & $\begin{array}{l}\text { G. Th. } \\
\text { Fechner }\end{array}$ & W. Prinz \\
\hline $\begin{array}{l}\text { Humanistic } \\
\text { psychology }\end{array}$ & History & $\begin{array}{l}\text { Understanding the individual in } \\
\text { his or her experience and be- } \\
\text { havior, uniqueness and incom- } \\
\text { parability of the individual }\end{array}$ & $\begin{array}{l}\text { J.W. v. Goethe } \\
\text { W. Dilthey }\end{array}$ & $\begin{array}{l}\text { L. Klages } \\
\text { P. Lersch }\end{array}$ & N. Groeben \\
\hline $\begin{array}{l}\text { Social- } \\
\text { scientific } \\
\text { psychology }\end{array}$ & Sociology & $\begin{array}{l}\text { Experience and behavior are } \\
\text { learned in the course of sociali- } \\
\text { zation and reflect social circum- } \\
\text { stances }\end{array}$ & $\begin{array}{l}\text { J. Locke } \\
\text { M. Weber }\end{array}$ & F.H. Allport & H.W. Baltes \\
\hline $\begin{array}{l}\text { Biological } \\
\text { psychology }\end{array}$ & Biology & $\begin{array}{l}\text { Tendencies of experience and } \\
\text { behavior are embedded geneti- } \\
\text { cally and developed in the in- } \\
\text { terplay of mutation and selec- } \\
\text { tion during the evolution proc- } \\
\text { ess. }\end{array}$ & Ch. Darwin & K. Lorenz & I. Eibl-Eibesfeldt \\
\hline
\end{tabular}




\section{2 "Forces" (= motivation) and "Functions" (= cognition)}

When asking specifically which conditions are behind human experience and behavior, completely different levels of analysis and various steps of differentiation can of course be distinguished. Rohracher (1988) provides a fairly rough, simplifying but clear classification which distinguishes between "forces" and "functions". Forces listed for example as needs, wishes, urges, motives or desires - push humans towards goals. To find these goals the individual requires the functions, i.e. perception, thinking, memory. Forces without functions are - in Rohracher's words - "blind" whereas functions without forces are "empty". Even today the basic idea of this differentiation - although demarcations differ in detail - is visible in the distinction between motivation and cognition, those fields that constitute the main areas of fundamental research in general psychology.

\subsection{Person and situation - Kurt Lewin's behavioral formula}

Psychological research approaches constantly run into the danger of falling back solely onto determinants inside the person when explaining behavior, the same forces and functions which are then to be identified using suitable psychological research methods. Determinants of behavior which lie within the situation are often implicitly or even explicitly omitted in the analysis. The first to criticize this in a programmatic way was the highly influential gestalt and social psychologist Kurt Lewin (1936), who interpreted any behavior as a function of the person and of the situation, and who designed this within the framework of his topological psychology also in a theoretically sophisticated way. It is ultimately the context of the respective behavior, i.e. the situation that motivated the emergence of different schools of applied psychology. General psychology, oriented toward fundamental research, and its subject being in general terms the experience and behavior of the adult "healthy" average person, thus appears context-free. When including the respective behavioral context, e.g. the judiciary, traffic, or even the organization, in the consideration, fields such as forensic, traffic and organizational psychology emerge, which are in their research intentions not only aimed at generating an insight but also benefits in practice and for practice.

When differentiating the causes of human behavior a bit further, yet staying on a relatively general level, we can distinguish between "volition" and "ability" for the person, "empowerment" and "obligation" for the situation as well as the "situational enabling” (v. Rosenstiel, 1982; v. Rosenstiel \& Nerdinger, 2011). This is shown in Figure 2.

If an employee's behavior does not meet the expectations, the questions to ask are whether

- he could not do it,

- he did not want to do it,

- he was not allowed to do it,

- he did not have the necessary resources or if there were impeding barriers. 
Figure 2: Conditions of behaviour

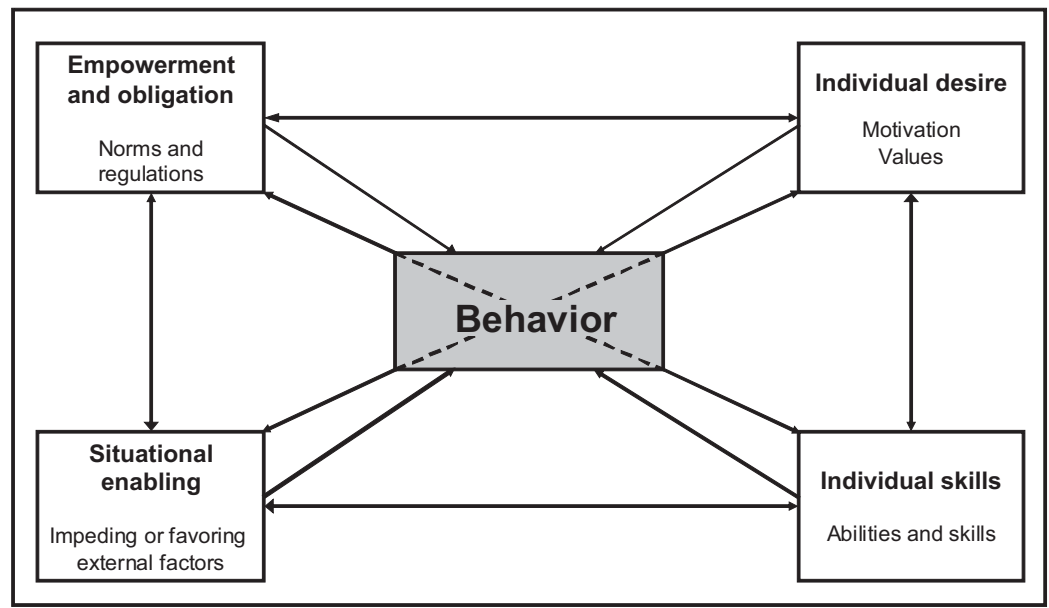

\subsection{Behavior and action}

A change in the underlying fundamental concept, which can be found throughout the theoretical basic subjects and the various applied disciplines of psychology, becomes evident in the distinction between behavior and action. In the behavioral concept, as it was explicitly represented in American behaviorism (Watson, 1913; Skinner, 1938), the individual is largely considered to be unmotivated and passive, his behavior is activated or triggered by external stimuli and stabilized, reinforced and affirmed by the consequences, which ultimately turns the human being into a marionette of external conditions. The concept of action, in contrast, assumes that the individual actively sets his goals and seeks to achieve these systematically (Tomaszewski, 1978; Leontjew, 1979; Hacker, 2005). This was not without consequences, neither for the analysis nor for the interpretation of behavior or action of employees in organizations (Frese \& Sabini, 1985).

\section{Experience and behavior in organizations - the field of work and organizational psychology}

Experience and behavior or actions of people in organizations is not only - but particularly - analyzed by work and organizational psychology, a subject which - although with various names such as "scientific management" (Taylor, 1911), psychotechnology (Giese, 1927), industrial psychology (Mayer \& Herwig, 1963) etc. - has been pursued since the beginning of the $20^{\text {th }}$ century, i.e. soon after the installation of psychology as an academic discipline in Leipzig, Germany, in 1879. In the process organizational psychology is at times conceived as part of work psychology (Hacker, 1980), sometimes work psychology as part of organizational psychology (v. Rosenstiel \& Nerdinger, 2011) and in some views industrial and organizational psychology are on an equal footing (Greif, Holling, \& Nicholson, 1989). In recent times "personnel psychology" is sometimes singled out from the over-arching work and organizational 
psychology. Here we will limit ourselves to the term organizational psychology, the subject of which is the experience and behavior of employees in organizations and therefore also involves the work behavior displayed there. We will not cover work outside of organizations, e.g. that of self-employed workers or housewives.

In its history of more than a century work and organizational psychology has developed a wide body of knowledge of methodology and content and also some remarkable theoretical conceptions, which are reported on in several volumes in the Enzy klopädie der Psychologie (encyclopaedia of psychology) (Schuler 2005; Frey \& v. Rosenstiel, 2007; Kleinbeck \& Schmidt, 2009; Zimolong \& Konradt, 2009). One could naively believe to find a representative overview there of what can be said about the behavior of employees in organizations from a scientific perspective. That is not the case, as for various reasons there are restrictions and one-sidedness, which will be addressed now.

\subsection{Limitations and restrictions}

From different perspectives research in organizational psychology shows- no matter whether conducted by psychologists, sociologists or economists - one-sided views which distort the knowledge about the subject - the behavior of employees in organizations - as the following keywords illustrate.

\section{Management orientation}

Particularly in the 70s Marxists accused the "bourgeois" field of work and organizational psychology of serving the capital with their research and activities, specifically work intensification and the stabilization of the system (Groskurth \& Volpert, 1975). Examples are research paths serving performance intensification, studies on the motivating effects of remuneration systems or job design, and with regard to the stabilization of the system there are measures for increasing job satisfaction or mediation of interpersonal conflicts in organizations. Content analyses of favored research topics in US American or German journals show that this allegation is by no means made up out of thin air (v. Rosenstiel \& Woschée, 2002). Such topics were indeed often objects of research with the purpose - directly or indirectly - of increased employee performance and the efficiency of leadership measures, while those questions, where answers could be conducive to promoting the enforcement of workers' interests, protect them from the adverse impacts of stress or generally stabilize their well-being, play a rather minor role.

\section{Work and performance behavior}

The diversity of behavior that people show in organizations is nearly unlimited. They tell various stories and jokes at work, celebrate successes together, comfort each other in the case of failure, fall in and out of love, shirk work, conspire against their superiors, develop peculiar rituals or knowingly exhibit behavior patterns that shake existing norms and are ostensibly directed against the interests of the organization. All of this is only briefly touched or can be found in publications that are rather met with surprise or ridicule (Neuberger, 1988, 2006; Mainiero, 1986; Micheli \& Near, 1991). It is almost exclusively that kind of work and performance behavior or organizational conditions and behavior that become the subject of the analysis, which serve in the authors' implicit or explicit view of the performance target. 


\section{Cognitive conditions of behavior}

Influenced by the theory of action (Frese \& Sabini, 1985) and the concepts related to it, e.g. the widespread view of action regulation that can be found in recent work psychology (Hacker, 1986), the explanation of work and performance behavior was primarily cognitive, which is reflected in terms such as "TOTE model", "operative image system", "redefinition of the task", planning or goal orientation etc.. Motivation processes, in contrast, or even those of volition are rather neglected and only come to the fore in the analysis of entrepreneurial behavior (McClelland \&Winter, 1969), and feelings are barely considered - even in concepts of motivational regulation (cf. however Kannheiser, 1992). Only with a growing trend in person-related services (Nerdinger, 1994) and the analysis of what is known as emotion work (Hochschildt, 1990), can a somewhat more intense discussion of emotions at work be stated.

\section{Leadership and manager behavior}

Bearing in mind the diversity of players in organizations - even with restriction to work behavior - it is not surprising that research is primarily directed at the behavior of senior staff and managers, where the focus is also on activities with rational and economic objectives and not their "games", their micro-political activities, their strategies for preserving power and influence or their generally "irrational" approaches to people and tasks (Neuberger, 1976, 2006). Besides the everyday behavior of senior staff and particularly their leadership style, the relevant research - mainly that in work psychology - has mostly dealt with production workers - preferably with assembly line jobs in the automobile industry - or with a work situation arising in the wake of the assembly line, namely call centers. Other types of behavior, as they are becoming more and more frequent within the knowledge and information society or in turning toward services, have been paid little attention (Nerdinger, 1994) and capture only tentatively the interest of the relevant sciences.

\section{Dominance of survey methodology}

Looking at the diversity of existing research methods in empirical social science, it is striking that the survey, whether in the from of a face-to-face interview or an anonymous written mass survey (increasingly to be found in the intra- and internet) in the field, dominates in the analysis of employee behavior in organizations (Thomas, 1984). This method entails a number of advantages, in particular it allows for collecting large amounts of data in a relatively economical way, but the disadvantages of surveys have often been described and are well-known. Against this background it is unfortunate as well as surprising that systematic and unsystematic observation - presumably mainly for reasons of research economy - is clearly underrepresented in the analysis of our object of interest.

\section{Linking data from one source}

If one accepts the statement that an empirical science is about describing an object, explaining it, predicting its appearance and providing possibilities of exerting influence, i.e. control, data linkage becomes a central question - not taking into account the phase of description. Which condition (independent variable) leads under which 
specific circumstances (intervening variable) to which outcomes (dependant variable)? Within psychologically-oriented survey studies all these variables are usually obtained from one data source, namely the statements of the respondents, and interpreted as cause or consequence within the framework of specific theories or linking hypotheses. Experiments which could provide a clearer statement regarding causality are rarely carried out; the same holds for costly longitudinal studies, which would allow for statements regarding causality which are slightly more validated. In particular it must be clear that there is a great risk in inferring the object to be studied when linking statements from a single data source, but that one often only encounters the subjective theories of those who were questioned.

\section{Positivistic approaches}

Even though there is time and again talk of a desirable combination of qualitative and quantitative research methods, approaches that, in a positivistic tradition, process quantitative data mostly with the help of descriptive or explanatory statistics still dominate when studying employee behavior in organizations. Action research or other forms of qualitative approaches still play a minor role. If at all, they can be found in case-by-case studies, in the analysis of organizational culture or in some forms of cross-cultural comparative studies.

\section{Declining reference to application}

In recent years there was a similar tendency in work, organizational and personnel psychology as in most natural and social sciences: the obligation to publish in English language journals with a high impact factor. This is increasingly becoming a requirement for a scientific career. The consequences for a more application-oriented field integrated in a specific culture are worrying. It is important to gain the acceptance of the mostly US American reviewers. Therefore very few issues that are typical for German personnel work are studied, hardly any qualitative methods are used, but increasingly it is experimental designs that have to be evaluated with elaborate quantitative methods which become the basis of the analysis and where psychology students serve as research subjects. All this is a deterrent to the practitioner. In addition to that the English language presents another obstacle (v. Rosenstiel, 2004; Kanning, v. Rosenstiel, \& Schuler, 2010). One can suspect that potentially useful findings of the field will hardly reach practice as a result of this development.

\subsection{Implicit images of man in transition}

In retrospect there were several attempts (Schein, 1965; Staehle, 1980; Ulich, 2005) to characterize the phases of the historic course of exploring human behavior in organizations with a sequence of changing implicit ideas of man. At the same time these ideas of man can be interpreted as implicit conceptions of man with a stereotype character, as patterns (Lord \& Maher, 1991) which underlie the relevant research concepts and channel the interpretation of research results. It can be assumed that their depiction of the facets of behavioral reality is quite valid, but must be interpreted as being one-sided.

Influenced by Taylor (1911) both the idea of "homo economicus", inspired by the economic sciences, who was solely motivated by individual wage incentives to do 
his job, but also the idea of the "homme machine", inspired by the engineering sciences, i.e. the view of a person, who must on the one hand be optimized as a technical device, and who, on the other hand, must be treated with care, dominated the beginning of the previous century. These basic ideas are still prevalent today. In nearly all models of the individual performance pay - up to the bonuses of financial managers they live on and can on the other hand be found in the ergonomically characterized work improvement up to the "system of predetermined times" (Schlaich, 1965).

This idea of man was fundamentally modified by the much noted Hawthorne studies (Roethlisberger \& Dickson, 1939), which were definitely based on Tayloristic basic assumptions, yet in the end interpreted their data in a way that informal group norms as well as social relations between managers and their staff ultimately determine performance behavior. These assumptions resulted in the idea of "social man" and established the "human relations movement" which was widely criticized later. Nevertheless the aftereffects of this concept can be found in research and practice when it, for example, comes to studies on the impact of cohesion in work groups, the working climate in the company or employee-oriented leadership.

Inspired by humanistic psychology, which opposed the homeostatically characterized deficit models in human motivation and instead made the target of growth, of self-actualization the center of focus (Maslow, 1954), the idea of "self-actualizing man" developed, a human being seeking to develop and to actualize himself in his professional behavior, who likes to take responsibility and for whom selfdetermination is more important than material remuneration. This led to the respective conceptions of job (Herzberg, Mausner, \& Snyderman, 1959) as well as organizational design (McGregor, 1960), which have their common ground in ensuring a larger scope of action at work for the employee, e.g. via job enlargement, job enrichment, delegation as a leadership principle, systems of management by objectives or other forms of work organization that emphasize the freedom and personal responsibility of the employee (Ulich, Groskurth, \& Bruggemann, 1973). Up until today this conception is considered in political directives when dealing with workers' participation or work humanization.

Finally it was realized that all these ideas of man have to be seen as simplifications and one-sided views and must not be generalized. In the course of their biographies and depending on the respective situation, individuals can be interpreted in different ways. Moreover they differ considerably on the interindividual level so that in the end one would make assumptions based on a conception of the "complex man". Impacts are evident today, e.g. in the request for a differential job design (Ulich, 1978).

\section{Stable personal traits and their effects}

In no other field is there as much knowledge about the reasons for human behavior in organizations - particularly about their performance behavior and performance results - than in that of measuring stable personal traits and their impacts. Comprehensive reference books document measuring methods common in this field (Sarges \& Wottawa, 2004; Erpenbeck \& v. Rosenstiel, 2007) as well as the behavior correlates of the relevant measurement results (Schuler, 2001; 2006). In line with the "trimodal approach" (Figure 3) mostly tests for recording characteristic traits, simulations like 
Figure 3: The "trimodal approach" of personnel assessment

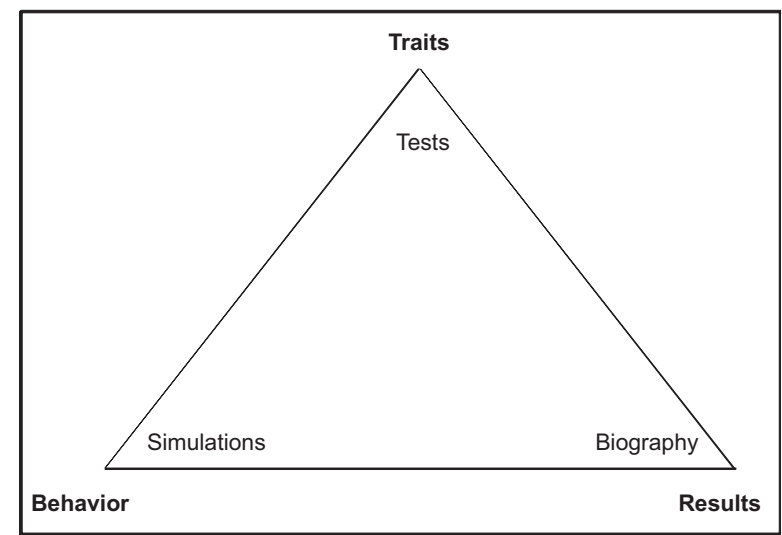

work samples and assessment centers for behavior predictions and biographic analyses or structured interviews for the assessment of future work results are used. A restriction to examples is required here.

\subsection{Cognitive traits (intelligence)}

Since the last decade of the $19^{\text {th }}$ century intelligence has been systematically recorded in various fields with standardized measurement processes and since the beginning of the $20^{\text {th }}$ century it has been consulted as a basis for systematic demand-oriented personnel selection (Schuler, 2006). Since then the measuring of intelligence has been systematically differentiated and refined. Operationalizations are available not only for this personality trait ("general factor") but also for more narrowly described specifications and factors. The vast number of studies on correlates of behavior and results of intelligence in organizations is impressive; information about the generalizable and secured results is provided by a number of meta-analyses (cf. Table 1) (e.g. Schmidt \& Hunter, 1998). Studies point to coefficients between intelligence and performance of sometimes more than 0.50 so that a considerable proportion of variance in terms of an incremental validity (Schmidt \& Hunter, 1998) hardly remains for indicators apart from intelligence (cf. Table 2). The prognostic strength of intelligence proves itself not only when it comes to the prediction of performance behavior and performance results but also regarding a number of other behavior patterns in organizations, e.g. social and team behavior.

Table 1: Average correlation between intelligence and different indicators of research success in compilations or meta-analyses (examples)

\begin{tabular}{l|c|c}
\hline Author & Year of publication & Correlation \\
\hline Stogdill & 1948 & .26 \\
\hline Neuberger & 1976 & .25 \\
\hline Schmidt \& Hunter & 1998 & .51 \\
\hline Ree \& Caretta & 1998 & .50 \\
\hline Schmidt \& Hunter & 2000 & .58 \\
\hline Jugde, Colberg, \& llies & 2004 & .27 \\
\hline
\end{tabular}


Table 2: Meta-analytically calculated validity and incremental validity of methods in personnel assessment (abridged according to Schmidt \& Hunter, 1998, p. 22)

\begin{tabular}{l|c|c}
\hline Predictor & Validity & Incremental validity \\
\hline General cognitive capability tests & .51 & .12 \\
\hline Work samples & .54 & .14 \\
\hline Integrity tests & .41 & .09 \\
\hline Conscientiousness tests & .31 & .12 \\
\hline Structured job interview & .51 & .04 \\
\hline Unstructured job interview & .38 & .07 \\
\hline Expertise tests & .48 & .07 \\
\hline Probation period & .44 & .01 \\
\hline Biographical data & .35 & .02 \\
\hline Assessment center & .37 & .01 \\
\hline Interests & .10 & .00 \\
\hline Graphology & .02 & \\
\hline
\end{tabular}

\section{2 "Personality traits"}

Apart from intelligence the prognostic value of other stable characteristics of the person, for which standardized test procedures exist, has been measured in numerous studies in order to predict behavior patterns that are of interest to the organization. In fact, a fairly good explanation of variance was attained at times through characteristics

Table 3: Results of second order meta-analysis: correlation with performance indicators (Barrick, Mount, \& Judge, 2001)

\begin{tabular}{|c|c|c|c|c|c|}
\hline & $\begin{array}{c}\text { Neuroticism } \\
\mathrm{N}\end{array}$ & $\begin{array}{c}\text { Extraversion } \\
\text { E }\end{array}$ & $\begin{array}{c}\text { Openness } \\
0\end{array}$ & $\begin{array}{c}\text { Agreeableness } \\
\text { A }\end{array}$ & $\begin{array}{l}\text { Conscientious- } \\
\text { ness } \\
\text { C }\end{array}$ \\
\hline \multicolumn{6}{|l|}{ Work performance } \\
\hline $\begin{array}{l}\text { Independent } \\
\text { meta-analyses }\end{array}$ & -.13 & .15 & .07 & .13 & .27 \\
\hline $\begin{array}{l}\text { Partly overlapping } \\
\text { meta-analyses }\end{array}$ & -.15 & .15 & .07 & .11 & .24 \\
\hline \multicolumn{6}{|l|}{$\begin{array}{l}\text { Specific performance } \\
\text { criteria }\end{array}$} \\
\hline Appraisal by superiors & -.13 & .13 & .07 & .13 & .31 \\
\hline Objective criteria & -.10 & .13 & .03 & .17 & .23 \\
\hline Training performance & -.09 & .28 & .33 & .14 & .27 \\
\hline Team work & -.22 & .16 & .16 & .34 & .27 \\
\hline \multicolumn{6}{|l|}{$\begin{array}{l}\text { Specific occupational } \\
\text { groups }\end{array}$} \\
\hline Sales & -.05 & .11 & -.03 & .01 & .25 \\
\hline Management & -.09 & .21 & .10. & .10 & .25 \\
\hline Professionals & -.06 & -.11 & -.11 & .06 & .24 \\
\hline Police & -.12 & .12 & .03 & .13 & .26 \\
\hline Industrial & --- & .06 & .05 & .10 & .23 \\
\hline
\end{tabular}


such as extraversion, emotional stability, readiness to assume a risk, belief in selfefficacy, interest etc. The results, however, hardly proved to be generalizable. They only proved their explanatory strength with regard to very specific requirements in narrowly defined situations. One example is the "big five" (Costa, McCrae, \& Arenberg, 1980; Ostendorf \& Angleitner, 2004), that personality psychology has mainly focused on in recent years. Here it was only - when orienting oneself on meta-analyses (Barrick, Mount, \& Judge, 2001) - conscientiousness which could prove a continuously moderate positive correlation with performance indicators, while emotional instability ("neuroticism") shows a continuously negative yet low forecasting quality. The other characteristics, i.e. extraversion, openness to experience and agreeableness, generally show only widely dispersed values, even though the coefficients reach remarkable expressions for specific situations (cf. also Judge, Higgins, Thorensen, \& Barrick, 1999 as well as Tett, Jackson, \& Rothenstein, 1991). The remaining findings are that personality traits such as the ones mentioned here are only suitable for behavior forecasts with a specific formulation of the criterion for success.

\subsection{Motivation, volition, and interests}

Motivation, volition, and interests can be assigned to the previously mentioned mental abilities (Rohracher, 1988) which can bring people to show a specific behavior permanently and intensively also in case of resistance or to link themselves to certain fields and to specifically deal with them. It is plausible that interests are helpful for specific behavior forecasts. Someone who has a pronounced technical interest will obviously act more successfully in the respective field than someone with less pronounced relevant interests but generally with the same cognitive capabilities. It should, however, not be overlooked that interests often - in a way as a "dependent variable" - develop subsequently when dealing with a certain field of content for a longer time (Seifert, 1977).

The situation is different for motives specified with regard to content, which are often interpreted partly as genetically based, partly as influenced by upbringing. Particularly McClelland's and his scholars' research (McClelland, 1985) was groundbreaking, i.e. it differentiates between the classification suggested by this author into achievement, power and affiliation motivation. The achievement motive proves to be very potent for predictions of behavior in various fields. A highly pronounced achievement motive with otherwise equal capabilities brings about unexpectedly high achievement results ("overachievement"), while a low achievement motive leads to underachievement accordingly. The power motive, on the other hand, is well-suited for the prediction of assertiveness in interpersonal fields and control over others and therefore for the prediction of careers in organizations.

There was a considerable research interest in volition - which could colloquially be called 'will' - at the beginning of the $20^{\text {th }}$ century, which was then largely "forgotten" but which has recently become a much researched topic (Heckhausen, Gollwitzer, \& Weinert, 1987; Kehr 2004). A strong expression of volition can contribute in various fields to overcoming inner resistances, to protect against distraction and to consequently pursue a goal. 


\subsection{Job satisfaction}

It may be surprising to find job satisfaction brought up in this context, as it is mostly viewed as an attitude to different facets of the work situation (Neuberger \& Allerbeck, 1978) and therefore as a dependent variable resulting from specific perceived and evaluated characteristics of work and of the organization, e.g. the job content, leadership behavior of the superior or remuneration. It has only recently become clear that it also has to be viewed as a stable personality trait to a significant proportion of variance, which is apparently also genetically based (Judge \& Locke, 1993; Brandstätter, 2006). Therefore job satisfaction can also be understood as an independent variable, which seems suitable to predict relatively stable behavior variables which are of interest to the organization, such as a disposition to absenteeism or resignation.

\subsection{Consequences for personnel decision making}

The capturing of stable personality traits, as suggested in the examples here, is meanwhile of considerable significance for personnel decision making, e.g. in staff selection, relocation and transfer, advancement and promotion as well as in career counseling. As the validity of established methods has been well studied, they can certainly serve as a basis for calculating the benefit in an economic sense, i.e. the costs of a wrong decision for the organization can be determined and the profit connected to the right one (Görlich \& Schuler, 2006).

\section{Variable characteristics of a person and their impacts}

Nearly all personality traits that can be diagnosed in adults - whether cognitive or motivational - are genetically based to a certain extent and therefore largely stable. Another part is the result of conscious or unconscious experiences and in this sense usually variable. Dealing with the explicit or implicit requirements of the organization and the specific job therefore leads to changes in personality of the employee in the sense of a professional socialization ("becoming social"), partly the person is specifically developed ("making social") through operational measures or self-organized activities of the individual - usually for optimizing a fit with future requirements.

\subsection{Selected findings}

The human being is able to learn and be flexible to a considerable extent, which is why many characteristics change and develop in the course of job socialization. For example, monotonous industrial work leads to a reduction of cognitive skills (Greif, 1978), repetitive tasks to a narrowing of interests and of self-controlled social activities (Grüneisen \& Hoff, 1977), social stress to a decrease of empathy and emotional responsiveness, which can eventually even lead to burnout (Nerdinger, 1994) etc., but also to building skills, a transformation of job interests, to the development of competencies in the course of doing the job and through the social environment. Research on socialization in and through organizations proves this impressively. But while this "becoming social" is generally not intended, organizations actively promote building specific personality traits in a targeted and demand-oriented way through "making social" in the course of human resource development, which involves much more than the intended, institutionalized further education and training with its focus on learning 
objectives (Sonntag, 2006). It seems, in fact, that the greater part of skills, which will be necessary in the future for coping with changing requirements, is developed by implicit learning in the work process and in the social environment. Some authors speak of approximately $80 \%$ in this context, which has led to the provocative thesis that further education is a myth that is breaking (Staudt \& Kriegesmann, 1999). In fact, much of what is required in the company of the job holder or what will in the future constitute the requirements is gained on the job itself, through specific job rotations, stays abroad, observation of successful job holders, informal contacts, experience from outside the workplace etc. so that a deliberate and goal-oriented institutionalized personnel development through further education and training forms only the smaller, though more intensively researched part. However, the thesis that this kind of HR development "doesn't work anyway" can be disproved based on empirical analyses. Although ever so carefully planned development measures often fail because the transfer of learning, i.e. the transfer of the knowledge gained in the training into practice, is not specifically facilitated, but meta-analyses show that content- as well as process-related HR development measures may well be successful. The meta-analysis of Arthur, Benett, Edens \& Bell (2003) is one example to prove this. In their study the authors refer to 636 sources where the aim was the evaluation of HR development measures and which were published between 1960 and 2000. Kirkpatrick's (1987) criteria were applied as indicators of success, i.e. subjective reactions, improvement of knowledge, change of behavior and "hard" performance improvements. The analysis, which is shown in Figure 4, proves that personnel development can well be successful, but that success can vary widely depending on many auxiliary conditions.

Figure 4: Effects of training in organizations (Source: Arthur et al., 2003, pp. 234-245)

A meta-analysis on the effect of trainings

Question: What is the effect of training in organizations?

Method: Meta-analysis

Basis: All publications in professional journals on the effectiveness of training in organizations (1960 - 2000) $\mathrm{N}=636$ sources

Criteria for final selection:

- "reactions" - subjective self-report of trainees

- "learning" - knowledge enhancement

- "behavior" - behavior change

- "results" - "hard" performance enhancement

Analytical results: With regard to all four criteria on average medium to good effects, strongest in knowledge enhancement. There is a large difference in the effect depending on learning content and methodology.

A combination of different methods is advisable!

Surprising: a lecture with discussion is on average not less effective than other methods!

\subsection{Consequences for human resource development}

Human resource development is often restricted to the conception and conduction of specific measures in further education and training. This does not to justice to the phenomenon. Those measures which allow for specific implicit learning should also be implemented, e.g. a well-planned curriculum of learning experiences in the course 
of job rotation, exchange of experiences with other successful co-workers, raising awareness for and passing on implicit learning experience, building a culture of trust where mistakes and failures can be discussed openly and many others (Erpenbeck \& v. Rosenstiel, 2009).

\section{Effects of situational conditions on employee behavior}

The behavior of people in organizations is, as pointed out at the beginning, not only dependent on the characteristics of the person - psychological strength and functions -, but also on the general conditions, the rules, regulations, job descriptions and other explicit guidelines, but also on informal norms inside the group, "secret syllabuses" and the corporate culture, but also on hard conducive or obstructive conditions: resources or barriers. At times sociologists, political scientists or economists go so far as to assume that the individual behavior is almost exclusively determined by such influencing factors, e.g. (Luhmann, 1972), so that it hardly seems worthwhile to call on psychological variables for the prediction of human behavior in the organization. Empirical research results, as they have been outlined previously, show that such statements are exaggerated. The weight of the situational variable can, however, hardly be overestimated for descriptions, explanations, predictions and influencing of behavior.

\subsection{Job design}

The technical layout of the workplace, e.g. the assembly line in production or the software in the PC in the administration, but also the partly meticulous instructions on processes and targets (Hackman, 1969), limit the freedom for interindividual variances at work to a great extent. This is all the more true the more these processes are characterized by specialization, standardization and formalization (Payme, Fineman, \& Wall, 1976). When carrying out an order and condition analysis independent of the individual in such situations (Ulich, 2005), the observable behavior is largely explained by that; a personalized task analysis can then be abandoned (Frieling \& Sonntag, 1999). This changes to the extent to which the individual's scope of action is extended and there is the opportunity to freely choose and form contacts with others - also beyond official channels. The behavior is now to a much greater extent determined by the personal characteristics, whereby the interindividual variance is also extended at work.

\subsection{Group structures, processes and climate}

For various reasons more and more people work more often and longer in groups (Kleinbeck, 2006). It is also in groups where the most diverse formal and informal norms and structures form. Hierarchy is predetermined or battled out in terms of a "pecking order". Rules of behavior are introduced to the group as regulations or become an informal norm in the course of group dynamic processes, whose violation is sanctioned by the other group members. In this case the interindividual spread of behavior decreases with an increase in group cohesion (v. Rosenstiel \& Nerdinger, 2011), which also disproves the generalizing statement that there is a direct proportionality between group cohesion and group performance or that especially innovative results can even be expected (Irle, 1975). Based on informal processes of this sort a specific climate which is characteristic for the work group can be diagnosed which can 
be measured with suitable survey instruments (Brodbeck, Anderson, \& West, 2000; Kauffeld, 2001). Such a climate is usually characterized by the degree of peopleorientation, e.g. cohesion and the willingness to take responsibility as well as the degree of structuring in the sense of goal orientation and willingness to task mastery, which then again allows for behavior analyses of the group members.

In groups a clear role differentiation evolves because of specific role expectations and interpretations, i.e. there is the "alpha animal", the "follower", the "specialists", the "scapegoats" etc., whereby the formally appointed leadership can also be interpreted as a role. The leader largely determines the behavior of the other members which is his designated task -, which happens via direct communication on the one hand, but also via substitutes for leadership (Kerr \& Jermier, 1978; Türk, 1995), i.e. through hard and soft conditions such as incentive systems, objectives, job descriptions, cultural implicitness etc., which ultimately "tell" the group member what to do without the need for the superior to act directly (cf. Section 7).

\subsection{Organizational structure, climate and culture}

An organization and sections of this organization respectively determine the behavior of its members to a large extent. It has often been proven that the structuring of tasks, the concentration of authority, the kind of line control and the relative importance of auxiliary functions (Weber, 1922; Payne \& Pugh, 1976) determine individual behavior, e.g. the willingness and ability for innovative behavior and a more or less strong tendency toward interpersonal conflicts can be predicted. The organizational climate (Conrad \& Sydow, 1984; v. Rosenstiel \& Bögel, 1992) co-determines to a large extent how people deal with each other within the organization and what the situation is regarding their well-being at work; the organizational culture, the core of which are the habitual and conventional ways of thinking and acting in the company, which in turn suggests underlying values and which shows in symptoms such as verbal statements, interaction and artifacts (Neuberger, 1989; Schein, 2004), is not only suitable for explaining and predicting the economic success of a company within limits (Peters \& Waterman, 1984; Loisch, 2007), but also for determining the behavior of members of an organization in dealing with each other and in their demeanor to the outside world.

All in all these merely implied determining factors show that it is not sufficient to try and explain and predict the behavior of employees in an organization in a restricted way considering only the characteristics of the person.

\section{Excursion: Behavior of managers and leadership behavior}

Managers are also members of staff of the organization. Significantly more has been published on their behavior than on other groups of people in the company (Stogdill, 1974; Kieser, Reber, \& Wunderer, 1995; Wunderer, 2003; Neuberger, 2002; Wegge \& v. Rosenstiel, 2007). On the one hand the focus of empirical studies has been on the behavior of managers themselves (Mintzberg, 1973) but also (Neuberger, 1976, 2006) on how they influence the behavior of others, that of their staff in particular but also that of their colleagues and superiors.

There is by now a research tradition on the everyday actions of managers comprising more than 60 years (Carlson, 1951) with varying methodologies. The diary 
method has been used most frequently, i.e. cooperative managers wrote in their "diary" within a specified system of categories what they had just done. Less timeconsuming but possibly also less valid are attempts to have managers describe retrospectively what they did the previous day or the previous week. Significantly more complex are observation methods as employed by e.g. Mintzberg (1973), where senior managers were accompanied by a trained observer for a longer period, who took note of what the observed person did from morning until evening within a system of categories.

Such analyses of the everyday behavior of managers were carried out with samples of different sizes on different levels of hierarchy in completely different industries, whereby overview papers on central results (Schirmer, 1991; Neuberger, 2002) led to reasonably well-comparable results, which are at times contrasted with that kind of target leadership behavior which can be derived from normative concepts of rational-functional management. Table 4 provides an example for such a comparison following Stewart (1979).

Table 4: Everyday behavior of managers

\begin{tabular}{|l|l|}
\hline $\begin{array}{l}\text { Image of managers' work behavior } \\
\text { influenced by functional studies }\end{array}$ & $\begin{array}{l}\text { Image of managers' work behavior } \\
\text { influenced by activity-based studies }\end{array}$ \\
Sorted & $\begin{array}{l}\text { Fragmented, varied and short } \\
\text { Planned }\end{array}$ \\
Cooperation with superiors and subordinates & $\begin{array}{l}\text { Significance of lateral and external contacts } \\
\text { Fixed contacts, formal information paths }\end{array}$ \\
& $\begin{array}{l}\text { Development and fostering of reciprocal relations; informal } \\
\text { paths }\end{array}$ \\
Use of official information & Use of informal, speculative information \\
Non-political & Political \\
Rather free of conflicts & Conflict-laden \\
\hline
\end{tabular}

We can see that more than half of a manager's work time is filled with verbal communication, that their work day is often reactive and unplanned and ad hoc reactions occur to a great extent, that networking and informal contacts play a major role, that behavior is interspersed with conflicts and micro-politics, that there is little time for reflection and only a relatively small amount of time is dedicated to direct subordinates, which - with a considerable spread from time to time - is usually just under $20 \%$.

This time dedicated to direct subordinates has been met with particular interest by leadership and organization research with a behavioral scientific focus, whereby the catchword of personal leadership comprised those deliberate and targeted courses of action which meant to influence the behavior of those who are managed in a communicative way (v. Rosenstiel, Molt, \& Rüttinger, 2005). This research initiated a lively discussion on leadership behavior and leadership styles and their impact. The experimental studies on leadership styles, which were carried out by Lewin, Lippitt \& White (1939), drew particular interest, whereby subsequent research was based on contrasting authoritarian and cooperative behavior. The difference between these two leadership styles lies primarily in the degree of participation granted to the subordinates in 
decision making processes, which was originally operationalized by assigning roles in the experiment, but was later also transferred to field studies (Seidel, 1978).

The findings of what is known as the Ohio State Leadership Studies (Fleishman, 1973) became even more influential. Based on appraisals of leadership behavior by subordinates two behavior variables independent of each other were identified by factor analysis: initiating structure (task orientation) and consideration (employee orientation). The questionnaires which emerged from this research, e.g. the LDBQ (Halpin \& Winer, 1957) in English-speaking and the FVVB by Fittkau-Garthe (1970) in Germanspeaking countries, which ultimately defined leadership behavior operationally, were the most widely used instruments for the analysis of leadership behavior for four decades. It was only in recent times that the pair of opposites transformational vs. transactional leadership gained in importance, whereby these behavior patterns were also operationalized by means of a survey among subordinates, usually with the MLQ (Bass \& Avolio, 1990). Transformational leadership is based on the assumption that the subordinate is driven by enthusiasm which is sparked by the leader, because of charisma, symbolization, intellectual impulses and appreciation and gets him to show notable commitment even without any direct material reward. Transactional leadership in turn is based on the assumption of an exchange between leader and subordinate in terms of the market principle (e.g. employee performance on the one hand, advancement and promotion by the leader on the other).

The vast number of studies on the effects of leadership behavior on subordinates has not yielded any results that can be generalized so that we can conclude that there

Figure 5: Conditions of leadership success

\begin{tabular}{|c|c|c|c|c|}
\hline \multirow{3}{*}{$\begin{array}{l}\text { Leadership } \\
\text { personality e.g.: } \\
\text { - Intelligence } \\
\text { - Declarative and } \\
\text { procedural } \\
\text { knowledge } \\
\text { - "Big Five" } \\
\text { - Social competence }\end{array}$} & \multicolumn{3}{|c|}{$\begin{array}{l}\quad \text { Leadership situation e.g.: } \\
\text { - Culture and political system of the country } \\
\text { - Industry of organization } \\
\text { - Corporate governance and legal framework } \\
\text { - Organization structure and culture } \\
\text { - Function (Production, Finance, Marketing, R\&D, HR, etc.) } \\
\text { - Size, structure and climate of the group } \\
\text { - Personality traits of group members } \\
\text { - Power base and legitimization of leaders }\end{array}$} & \\
\hline & \multirow[b]{2}{*}{ 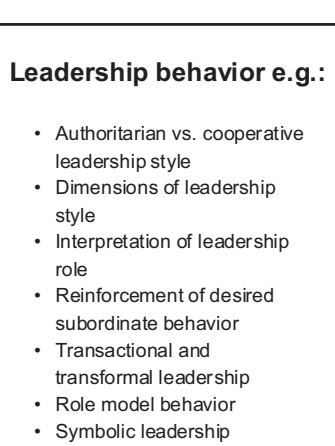 } & \begin{tabular}{|c|} 
Employee reactions \\
(human success)
\end{tabular} & \multicolumn{2}{|c|}{ Results (economic success) } \\
\hline & & $\begin{array}{l}\text { - Job satisfaction } \\
\text { - } \text { Commitment } \\
\text { - Self-directed } \\
\text { learning } \\
\text { - Qualification } \\
\text { - Dedication } \\
\text { - Team-oriented } \\
\text { behavior } \\
\text { - Absenteeism } \\
\text { - Resignation }\end{array}$ & $\begin{array}{l}\text { Disaggregated: } \\
\text { - Suggestions for } \\
\text { improvement } \\
\text { - Information costs } \\
\text { - Process and } \\
\text { product innovation } \\
\text { - Deviation from } \\
\text { plan } \\
\text { - Labor court } \\
\text { lawsuits } \\
\text { - Work accidents }\end{array}$ & $\begin{array}{l}\text { Aggregated: } \\
\text { - Growth } \\
\text { - Profit } \\
\text { - Turnover } \\
\text { - Market } \\
\text { share } \\
\text { - Productivity }\end{array}$ \\
\hline
\end{tabular}


is no "ideal leadership style". What kind of effect leadership behavior has on the subordinate depends on the given leadership target and on the situational conditions. This resulted in many so-called "situational theories of leadership" (e.g. Fiedler, 1967; Hersey \& Blanchard, 1969; Vroom \& Yetton, 1973). Summarizing the relevant state of research gives rise to a picture as shown in Figure 5.

\section{Conclusion: "Heaps of knowledge" and "black holes"}

For more than 100 years systematic research has been conducted on employee behavior in organizations in an empirical way. When trying to get an overview, one ends up with an ambivalent opinion. In terms of content and methods, research has apparently been extremely selective and probably also guided by interests. In line with a positivistic approach quite a lot was primarily compiled about work and performance behavior and its conditions with quantitative methods together with an in-depth analysis of the behavior of leaders as well as the impacts of these actions. There has also been a wide research interest in job satisfaction, presumably because satisfaction is considered a condition for better performance. Other types of behavior, which are presumably without any direct or indirect relation to performance targets, have, in contrast, been much less observed or even neglected. In short: There is a lot of knowledge in selected areas while other fields simply provide no incentive for further research and have so far largely been ignored.

In concrete terms: There is a lot of secured knowledge about determining the aptitude of employees for specific requirements. Their long-term value can be predicted fairly well. We also know a lot about the psychological foundations and the effects of personnel development measures. This applies also to the impacts of specific leadership behavior or the structures and processes in groups.

Considerably less research has been conducted on the behavior of employees in organizations which has no direct relation to performance. This applies also to the important field of impacts of specific work and organizational conditions on behavior. So there is still a lot to be done. This holds even more true considering that the context of the organization constantly continues to change faster and faster. This in turn means that research results regarding employee behavior, which today are considered relatively secured, can become void tomorrow. In natural sciences progress is usually based on the fact that more is known about a subject as research methods improve. In social sciences - which we are dealing with here - it is also the case that the subject itself is constantly changing.

\section{References}

Arthur, W. Jr., Benett, W. Jr, Edens, P. S., \& Bell, S. T. (2003) Effectiveness of training in organizations: A meta-analysis of design and evaluation features. Journal of Applied Psychology, 88, 234-245

Barrick, M. R., Mount, M. K., \& Judge, T. A. (2001). Personality and job performance at the beginning of the new millenium: What do we know and where do we go next? International Journal of Selection and Assessment, 9, 9-30.

Bass, B., \& Avolio, B. (1990). Transformational Leadership Development: Manual for the Multifactor Leadership Questionaire. Palo Alto: Consultig Psychologist Press.

Bischof, N. (1981). Aristoteles, Galilei, Kurt Lewin - und die Folgen. In W. Michaelis (ed.), Bericht über den 32. Kongreß der Deutschen Gesellschaft für Psychologie in Zürich (pp. 17-39). Göttingen: Hogrefe. 
Brandstätter, H. (2006). Veränderbarkeit von Persönlichkeitsmerkmalen aus sozial- und differenzialpsychologischer Sicht. In K. Sonntag (ed.), Personalentwicklung in Organisationen (S. 57-83). Göttingen: Hogrefe.

Brodbeck, F. C., Anderson, N., \& West, M. (2000). Teamklima-Inventar (TKI). Göttingen: Hogrefe.

Carlson, S. (1951). Executive behavior. A study in the work load and the working methods of managing directors. Stockholm: Strömbergs.

Conrad, P., \& Sydow, J. (1984). Organisationsklima. Berlin: de Gruyter.

Costa, P.T., McGrae, R. R., \& Arenberg, D. (1980). Enduring dispositions in adult males. Journal of Personality and Social Psychology. 7, 793-800

Erpenbeck, J., \& Rosenstiel, L. v. (eds.) (2007). Handbuch Kompetenzmessung (2nd ed.). Stuttgart: SchäfferPoeschel.

Fiedler, F. E. (1967). A theory of leadership effectiveness. New York: McGraw Hill.

Fittkau-Garthe, H. (1970). Dimensionen des Vorgesetztenverbaltens und ibre Bedeutung für die emotionalen Einstellungsreaktionen der unterstellten Mitarbeiter (Dissertation). Hamburg: Inst. für Psychologie

Fleishman, E. (1973). Twenty years of consideration and structure. In E. A. Fleishman \& J. G. Hunt (eds.), Current developments in the study of leadership (pp. 1-37). Carbondale: Southern Illinois University Press.

Frese, M., \& Sabini, J. (eds.) (1985). Goal directed behavior: The concept of action in psychology. Hillsdale, N.J.: Lawrence Erlbaum.

Frey, D., \& Rosenstiel, L. v. (eds.) (2007). Ensyklopädie der Psychologie: Wirtschaftspsychologie. Göttingen: Hogrefe.

Frieling, E., \& Sonntag, K. (1999). Lehrbuch Arbeitspsychologie (2nd ed.). Bern: Huber.

Giese, F. (1927). Methoden der Wirtschaftspychologie. Berlin: Urban \& Schwarzenberg.

Görlich, Y., \& Schuler, H. (2006). Personalentscheidungen, Nutzen und Fairness. In H. Schuler (ed.), Lebrbuch Personalpsychologie (pp. 797-840). Göttingen: Hogrefe.

Greif, S. (1978). Intelligenzabbau und Dequalifizierung durch Industriearbeit? In M. Frese, S. Greif \& N. Semmer (ed.), Industrielle Psychopathologie (pp. 232-256). Bern: Huber.

Greif, S., Holling, H., \& Nicholson, N. (1989). Arbeits- und Organisationspychologie. München: Psychologie Verlags Union.

Groskurth, P., \& Volpert, W. (1975). Lohnarbeitspsychologie. Frankfurt a. M.: Fischer.

Grüneisen, V., \& Hoff, E. (1977). Familienerziehung und Lebenssituation. Weinheim: Beltz.

Hacker, W. (1980). Handlungsregulation: zur aufgabenabhängigen Struktur von handlungsregulierender mentaler Repräsentationen. In Kongreßbericht. Leipzig: Institut für Psychologie.

Hacker, W. (1986). Arbeitspsychologie. Psycbische Regulation von Arbeitstätigkeiten. Bern: Huber.

Hackman, J. R. (1969). Toward understanding the role of task in behavioral research. Acta Psychologica, 31, 97-128.

Halpin, A. W., \& Winer, B. J. (1957). A factorial study of the leader behavior description. In R. M. Stogdill \& A. E. Coons (eds.), Leader behavior: Its description and measurement (pp. 39-51). Columbus: Administrative Science.

Heckhausen, H., Gollwitzer, P. M., \& Weinert, F. E. (1987). Jenseits des Rubikon. Berlin: Springer.

Hersey, P., \& Blanchard, K. H. (1969 (German 1979)). Management of organizational behavior: utilizing human resources. Englewood Cliffs, N.J.: Prentice-Hall.

Herzberg, F., Mausner, B., \& Snyderman, B. (1959). The motivation to work. New York: Wiley \& Sons.

Hochschild, A. (1990). Das gekaufte Herz. Zur Kommerzialisierung der Gefüble. Frankfurt: Campus.

Irle, M. (1975). Lebrbuch der Sozialpsychologie. Göttingen: Hogrefe.

Judge, T. A., Higgins, C. A., Thorensen, C. J., Barrick, M. R. (1999). The big five personality traits, general mental ability, and career success across the life span. Personal Psychology, 52, 621-652.

Judge, T.A., \& Locke, E. A. (1993). Effects of dysfunctional thought processes on subjective well-being and job satisfaction. Journal of Applied Psychology, 78, 475-490.

Judge, T.A., Piccolo, R.E. \& Illies, R. (2004) The forgotten ones? The validity of consideration and initiating structure in leadership research. Journal of Applied Psychology, 89, 36-51

Kannheiser, W. (1992). Arbeit und Emotion. München: Quintessenz. 
Kanning, U.P., Rosenstiel, v. L., \& Schuler, H. (eds.) (2010). Jenseits des Elfenbeinturms. Psychologie als nützliche Wissenschaft. Göttingen: Vandenhoeck \& Ruprecht.

Kauffeld, S. (2001). Teamdiagnose. Göttingen: Vlg. für Angewandte Psychologie.

Kehr, H. (2004). Motivation und Volition. Göttingen: Hogrefe.

Kerr, S., \& Jermier, J. M. (1978). Substitutes for Leadership: Their meaning and measurement. Organizational behavior and buman performance, 375-403.

Kieser, A., Reber, G., \& Wunderer, R. (eds.) (1995). Handwörterbuch der Fübrung (Ensylklopädie der Betriebswirtschaftslehre ; vol. 10). Stuttgart: Schäffer-Poeschel.

Kirkpatrick, D. (1987). Evaluation of training. In R. L. Craig (ed.), Training and development handbook: A guide to buman resource development (pp. 301-319). New York: McGraw-Hill.

Kleinbeck, U. (2006). Das Management von Arbeitsgruppen. In H. Schuler (ed.), Lebrbuch der Personalpsychologie (pp. 651-672). Göttingen: Hogrefe.

Kleinbeck, U., \& Schmid, K-H. (eds.) (2009). Arbeitspsychologie. Enzyklopädie der Psychologie. Göttingen. Hogrefe

Leontjew, A. (1979). Tätigkeit, Bewnßstein, Persönlichkeit. Berlin: Volk und Wissen.

Lewin, K. (1936). Principles of topological psychology. New York: McGraw Hill.

Lewin, K., Lippitt, R., \& White, R. K. (1939). Patterns of aggressive behavior in experimentally created social climates. Journal of Social Psychology, 10, 271-299.

Loisch, U. C. (2007). Organisationskultur als Einflussgröße. Wiesbaden: Gabler, Edition Wissenschaft.

Lord, R. G., \& Maher, K. J. (1991). Leadership and Information Processing: Linking Perceptions and Performance. London: Routledge.

Luhmann, N. (1972). Funktionen und Folgen formaler Organisation. Berlin: Duncker \& Humblot.

Mainiero, L. (1986). A review and analysis of power dynamics in organizational romances. Academy of Management Review, 11, 750-762.

Maslow, A. H. (1954). Motivation and personality. New York: Harper.

Mayer, A., \& Herwig, B. (1963). Handbuch der Psychologie. vol. 9: Betriebspsychologie. Göttingen: Hogrefe.

McClelland, D. C. (1985). Human motivaton. Glenview, IL: Scott.

McClelland, D. C., \& Winter, D. G. (1969). Motivating economic acbievement. New York: Free Press.

McGregor, D. (1960). The buman side of enterprise. New York: McGraw-Hill.

Micheli \& Near. (1991). Whistle blowing. Research in Organizational Behavior.

Mintzberg, H. (1973). The nature of managerial work. New York: Wiley and Sons.

Nerdinger, F. (1994). Selbstselektion von potentiellen Führungskräften. In L. v. Rosenstiel, T. Lang \& K. Sigl (eds.), Fach- und Führungskräfte finden und fördern (pp. 20-38). Stuttgart: Schäffer-Poeschel.

Nerdinger, F. W. (1994). Zur Psychologie der Dienstleitung. Stuttgart: Schäffer-Poeschel.

Neuberger, O. (1976). Führungsverhalten und Führungserfolg. Berlin: Duncker \& Humblot.

Neuberger, O. (1988). Was ist denn da so komisch?. Weinheim: Psychologie Heute TB.

Neuberger, O. (1989). Symbolisierung in Organisationen. Augsburger Beiträge zur Organisationspsychologie und Personalwesen, 4, 24-36.

Neuberger, O. (2002). Fübren und führen lassen. Stuttgart: Lucius.

Neuberger, O. (2006 ). Mikropolitik und Moral. Stuttgart: Lucius.

Neuberger, O., \& Allerbeck, M. (1978). Messung und Analyse der Arbeitszufriedenheit. Bern: Huber.

Ostendorf, F., \& Angleitner, A. (2004). NEO-Persönlichkeitsinventar nach Costa und McGrae. Göttingen: Hogrefe.

Payne, R., Fineman, S., \& Wall, T.A. (1976) Organizational climate and job satisfaction: A conceptional synthesis. Organizational Behavior and Human Performance. 16, 45-62

Peters, T. J., \& Waterman, R. H. (1984). Auf der Suche nach Spitzenleistungen. Was man von den bestgeführten USUnternebmen lernen kann. Landsberg: Moderne Industrie.

Roethlisberger, F. J., \& Dickson, W. J. (1939). Management and the worker. Cambrigde (Mass.): Harvard University Press.

Rohracher, H. (1988). Einführung in die Psychologie. München: Psychologie Verlags Union. 
Rosenstiel, L. v. (1977). Die Bedeutung der Wirtschaftspsychologie für die Wirtschaftslehrerbildung und die Wirtschaftslehre. In R. Buchegger et al. (eds.), Bezugswissenschaften der Wirtschaftslebre und Wirtschaftslehrerbildung (pp. 108-123). Trier: Spee.

Rosenstiel, L. v. (1982). Motivationsänderung in Organisationen. In H. Schuler \& W. Stehle (eds.), Psychologie in Wirtschaft und Verwaltung (pp. 289-305). Stuttgart: Poeschel.

Rosenstiel, L. v. (2004). Arbeits- und Organisationspsychologie - Wo bleibt der Anwendungsbezug? Zeitschrift für Arbeits- und Organisationspsychologie, 48, 87-97.

Rosenstiel, L. v. (2007). Grundlagen der Organisationspsychologie (7th ed.). Stuttgart: Schäffer-Poeschel.

Rosenstiel, L. v., \& Bögel, R. (1992). Betriebsklima geht jeden an. München: Bayerisches Staatsministerium für Arbeit, Familie und Sozialordnung.

Rosenstiel, L. v., Molt, W., \& Rüttinger, B. (2005). Organisationspsychologie (9th ed.). Stuttgart, Berlin, Köln: Kohlhammer.

Rosenstiel, L. v., \& Nerdinger, F. W. (2011). Grundlagen und Bezugsdisziplinen der Arbeits- und Organisationspsychologie. In H. Schuler \& K. Sonntag (eds.), Handbuch der Arbeits- und Organisationspsychologie (pp. 15-26). Göttingen: Hogrefe.

Rosenstiel, L. v., \& Woschée, R. (2002). Wertkonflikte in der arbeits- und organisationspsychologischen Forschung und Praxis. Zeitschrift für Personalforschung, 16(2), 187-208.

Sarges, W., \& Wottawa, H. (eds.) (2004). Handbuch wirtschaftpsychologischer Testverfahren. Lengrich: Pabst.

Schein, E. H. (1965). Organizational psychology. New York: Prentice Hall.

Schein, E. H. (2004). Organizational culture and leadership. San Francisco: Jossey-Bass.

Schirmer, F. (1991). Aktivitäten von Managern: Ein kritischer Review über 40 Jahre "Work Activity"Forschung. In W. H. Staehle \& K Sydow (eds.), Managementforscbung 1 (pp. 205-253). Berlin: DeGruyter.

Schlaich, K. (1965). Über die Bedeutung der Systeme vorbestimmter Zeiten im Arbeitsstudium. RefaNachrichten, 18 (3)

Schmidt, F. L., \& Hunter, J. E. (1998). Meßbare Personmerkmale: Stabilität, Variabilität und Validität zur Vorhersage zukünftiger Berufsleistungen und berufsbezogenen Lernens. In M. Kleinmann \& B. Strauss (eds.), Potentialfeststellungen und Personalentwicklung (pp. 16-43). Göttingen: Hogrefe.

Schuler, H. (ed.) (2006). Lebrbuch der Personalpsychologie. Göttingen: Hogrefe.

Seidel, E. (1978). Betriebliche Führungsformen. Stuttgart: Poeschel.

Seifert, K. H. (1977). Theorien der Berufswahl und der beruflichen Entwicklung. In K. H. Seifert (ed.), Handbuch der Berufspsychologie (pp. 171-279). Göttingen: Hogrefe.

Skinner, B. F. (1938). The behavior of organisms: An experimental analysis. New York: Appelton-Century.

Sonntag, K. H. (Hrg.) (2006). Personalentwicklung in Organisationen (3rd ed.). Göttingen: Hogrefe.

Staehle, W. (1980). Menschenbilder in Organisationen. In E. Grochla (ed.), Handwörterbuch der Organisation (pp. 1301-1313). Stuttgart: Poeschel.

Staudt, E., \& Kriegesmann, B. (1999). Weiterbildung: Ein Mythos zerbricht. In Arbeitsgemeinschaft Qualifikations-Entwicklungs-Management (ed.), Kompetenzentwicklung 99 (pp. 17-60). Münster: Waxmann.

Stewart, R. (1979). Diary-keeping. In Th. D. Weinshall (ed.), Managerial communication (pp. 33-54). London: Academic Press.

Stogdill, R. M. (1974). Handbook of leadership. New York: Free Press.

Taylor, F. W. (1911). The principles of scientific management. London: Harper and Brothers.

Tett, R. P., Jackson, D. N., \& Rothenstein, M. (1991). Personality measures as predictors of job performance: a meta-analytic review. Personnel Psychology, 44, 703-742.

Thomas, A. (1984). Entwicklung der Forschung in Arbeits-, Betriebs- und Organisationspsychologie. Psychologie und Praxis. Zeitschrift für Arbeits- und Organisationspsychologie, 4, 174-177.

Tomaszewski, T. (1978). Tätigkeit und Bewußtsein. Weinheim: Beltz.

Türk, K. (1995). Entpersonalisierte Führung. In A. Kieser, G. Reber \& R. Wunderer (eds.), Handwörterbuch der Fübrung (2nd ed., pp. 328-340). Stuttgart: Poeschel.

Ulich, E. (1978). Über das Prinzip der differentiellen Arbeitsgestaltung. Industrielle Organisation, 47, 566568. 
Ulich, E. (2005). Arbeitspsychologie (6th ed.). Stuttgart: Schäffer-Poeschel.

Ulich, E., Groskurth, P., \& Bruggemann, A. (1973). Neue Formen der Arbeitsgestaltung. Frankfurt a. M.: Europäische Verlagsanstalt.

Vroom, V. H., \& Yetton, P. (1973). Leadership and decision-making. Pittsburgh: University of Pittsburgh Press.

Watson, J. B. (1913). Psychology as the behaviorist views it. Psychological Review, 20, 158-177.

Weber, M. (1922) (2nd ed. 1924). Wirtschaft und Gesellschaft. Grundriß der verstehenden Soziologie. Köln: Kiepenheuer und Witsch.

Wegge, J., \& Rosenstiel, L. v. (2007). Führung. In H. Schuler (ed.), Lebrbuch Organisationspsychologie (pp. 475-512). Bern: Huber.

Wunderer, R. (2003). Führung und Zusammenarbeit. Eine unternehmerische Fübrungslebre (5th ed.). Neuwied: Luchterhand.

Zimolong, B., \& Konrad, U. (2009) (ed.). Ingenieurspsychologie. Enzyklopädie der Psychologie. Göttingen. Hogrefe 